\title{
Eläinten hyvinvointimerkinnän mahdollisuudet arvoketjun näkökulmasta
}

\author{
Niemi Jarkko K. ${ }^{1)}$, Väre Minna ${ }^{1)}$, Raussi Satu ${ }^{2)}$, Kauppinen Tiina ${ }^{2)}$, Latvala Terhi1 ${ }^{1)}$, Yrjölä Tapani ${ }^{3)}$ ja \\ Kiviholma Sanni ${ }^{3)}$ \\ 1)Luonnonvarakeskus, Latokartanonkaari 9,00790 Helsinki,jarkko.niemi@luke.fi, \\ minna.vare@luke.fi,terhi.latvala@luke.fi, \\ 2) Eläinten hyvinvointikeskus, Luonnonvarakeskus, Latokartanonkaari 9, 00790 Helsinki, \\ tiina.kauppinen@luke.fi,satu.raussi@luke.fi \\ 3)Pellervon taloustutkimus, Eerikinkatu28 A,00180 Helsinki, tapani.yrjola@ptt.fi, \\ sanni.kiviholma@ptt.fi
}

\section{TIIVISTELMÄ}

Kotieläintuotannon arvoketjun tuotantotapa ja toiminnassa noudatetut käytännön vaikuttavat sekä eläinten hyvinvointiin että toiminnan kannattavuuteen. Suomen elintarvikemarkkinoille on esitetty kehitettävän eläinten hyvinvointia kuvaava laatumerkintä. Eläinten hyvinvointi on tärkeä osa eläintuotannon kestävyyttä, mutta tärkeä osa kestävyyttä on myös se, että ketjun toimijat ja kuluttajat hyväksyvät laatumerkinnän taustalla olevan tuotantotavan. Tämän selvityksen päämääränä on kartoittaa tuotantoketjun taloudellista näkökulmaa eläinten hyvinvoinnista kertovaan merkintään. Toimijoiden näkökulmia teemaan kartoitetaan yhtäältä toimenpiteiden kustannuslaskennan sekä toisaalta teemakeskustelun tulosten pohjalta. Esimerkkinä tarkastelussa käytetään sikatuotantoa sekä kahdeksaa hyvinvointitoimenpidettä, jotka kohdistuvat hyvinvoinnin eri osa-alueille ja joiden etuja ja haittoja tarkasteltiin laskelmissa ja keskusteluissa. Eläinten hyvinvointimerkki on tuotantotapaa kuvaava laatumerkintä, jonka organisointi ja merkkiin liittyvät eläinten hyvinvointia kohentavat toimenpiteet aiheuttavat arvoketjulle lisäkustannuksia. Kustannuksia aiheutuu paitsi alkutuotannolle, myös elintarviketeollisuudelle ja päivittäistavarakaupalle. Alkutuotannossa kustannuksia aiheuttavat mm. lisätyö eri tuotantovaiheissa, mahdolliset tilalla tehtävät rakenteelliset muutokset sekä aineet ja tarvikkeet (esim. tonkimismateriaalit). Eläinten logistiikassa ja teollisuudessa kustannuksia aiheutuisi $\mathrm{mm}$. tuotteen erillään pidosta ja jäljitettävyydestä ja kaupassa markkinoinnista. Myös tuotantotavan dokumentointi sekä toiminnan ja tiedon hallinta aiheuttavat kustannuksia. Jotta toimijoilla olisi taloudellinen kannustin ottaa merkintä käyttöön, nämä kustannukset on saatava katetuksi joko markkinatuotoilla (pyytämällä tuotteesta korkeampaa hintaa, jos asiakas on sen valmis maksamaan) tai kohentuneen tuottavuuden kautta. Tuottavuushyötyjä voidaan saavuttaa esimerkiksi toimenpiteillä, jotka parantavat eläinten terveyttä. Hyvinvointimerkki voi myös olla apuna yritystoiminnan kehittämisessä sekä mahdollistaa korkeamman lisäarvon saamisen tuotteesta ja parantaa siten yritysten kilpailukykyä, tai tuottaa muita hyötyjä (esim. työhyvinvointi). Hintalisän saamiseksi markkinoilta on tärkeää, että merkintä yhtäältä tuottaa kuluttajille aitoa lisäarvoa ja toisaalta, että päivittäistavarakauppa ja muut jakelutiet ovat valmiita käyttämään merkintää. Toimijoiden mukaan hyvinvointia edistävät toimenpiteet eivät kuitenkaan saisi vaarantaa tuoteturvallisuutta.

Asiasanat: eläinten hyvinvointi, arvoketju, kustannukset, hyödyt

\section{Johdanto}

Eläintuotannon kestävyys koostuu kolmesta peruspilarista, joita ovat taloudellinen, yhteiskunnallinen ja ympäristökestävyys (mm. YK 2005). Eläintuotannossa yhteiskunnallisen kestävyyden keskeinen elementti on eläinten hyvinvointi: Tutkimusten mukaan kansalaiset pitävät eläinten hyvinvointia tärkeänä eläintuotannon laatukriteerinä ja ruoan ostopäätökseen vaikuttavana tekijänä (mm. Kotro ym. 2011, Lagerqvist ja Hess 2011, Clark ym. 2019). Esimerkiksi Cicia ja Colantuoni (2010) arvioivat metaanalyysissaan kuluttajien olevan valmiita maksamaan keskimäärin noin $14 \%$ lisähintaa eläinten hyvinvoinnista tuoteominaisuutena. Vaikka moni kuluttaja arvostaa tuotteiden laatua ja turvallisuutta, ovat he huolissaan tuotantotavoista (esim. Clark ym. 2019). Eurooppalaisessa eläinten hyvinvointibarometrissa (European Commission 2015) nykyistä parempaa huolehtimista tuotantoeläinten hyvinvoinnista toivoi $90 \%$ suomalaisista (EU 82\%). 
Suomen markkinoilla ei vielä ole kattavaa eläinten hyvinvoinnista kertovaa laatumerkintäjärjestelmää. Viime vuosina on kuitenkin ollut havaittavissa yhä enemmän kiinnostusta tällaisen laatumerkinnän kehittämiseen ja eläinten hyvinvoinnin tuotteistamiseen, ja markkinoille on jo tullut muun muassa maito-, sianliha- ja kananmunatuotteita, joiden tuotannossa ja markkinoinnissa on korostettu tiettyjä eläinten hyvinvointinäkökohtia. Ruokapoliittisessa selonteossa (MMM 2017) tuotiin esille tarve eläinten hyvinvointiin liittyvää laatumerkintään, jotta laadukkaan kotimaisen tuotteen markkinointi olisi paremmin mahdollista. Euroopan unionin (EU) neuvosto puolestaan antoi joulukuussa 2019 lauselman eläinten hyvinvoinnista, jossa osaltaan tuotiin esille myös laatumerkinnät (Council of the Euroopean Union 2019).

Kotieläintuotannon arvoketjun tuotantotapa ja toiminnassa noudatetut käytännön vaikuttavat sekä eläinten hyvinvointiin että yritystoiminnan kannattavuuteen. Tärkeä osa eläintuotannon kestävyyttä on, että ketjun toimijat ja kuluttajat hyväksyvät laatumerkinnän taustalla olevan tuotantotavan. Kotron ym. (2011) kyselyn mukaan elintarvikealan toimijat kokevat yleisesti ottaen etenkin kustannusten, osaamisen ja toiminnan vastuullisuuden lisääntyvän erilaisten laatujärjestelmien käyttöönoton myötä. Sen sijaan toiminnan kannattavuuden ja joustavuuden epäiltiin yleisimmin vähenevän. Jotta yrityksillä olisi kannustin omaksua eläinystävällisiä tuotantotapoja, eläinten hyvinvointimerkinnän käyttöönotosta aiheutuvien lisäkustannusten ja tulonmenetysten tulisikin olla pienempiä kuin sillä saatavat mahdolliset kustannussäästöt ja lisäeläintulot. Lisäksi taustalla vaikuttaa muita tekijöitä. Hansson ja Lagerkvist (2014) tunnistivat käyttöarvoja ja ei käyttöarvoja ("use and non-use values"), jotka liittyivät eläinten hyvinvointia koskevaan päätöksentekoon. Käyttöarvot liittyivät siihen, että yrittäjä pystyi jatkamaan liiketoimintaa, ansaitsemaan elantonsa, olematta liian sitoutunut maatilaan, sekä tuotteen laatuun ja työympäristöön. Ei käyttöarvot liittyivät kykyyn parantaa eläinten hyvinvointia edelleen, kärsimyksen välttämiseen, yrittäjän hyvinvointiin, eettisiin näkökohtiin, tunteeseen "tehdä oikein" ja siihen, että eläimet toimivat kuten niiden pitäisi. Nämä näkökulmat voidaan ottaa huomioon myös eläinten hyvinvointimerkintää kehitettäessä.

McInerneyn (2004) esittämän mallin mukaan eläinten hyvinvointiin panostaminen nostaa aluksi myös tuottavuutta. Kuitenkin tietyn pisteen jälkeen eläinten hyvinvoinnin parantaminen alkaa laskea tuottavuutta. Mallin mukaan uuden, korkeamman eläinten hyvinvointistandardin käyttöön ottaminen siis nostaa hyvinvoinnin vähimmäistasoa, mutta voi heikentää tilan tuottavuutta. On kuitenkin vähän tutkimusnäyttöä siitä, missä määrin eläinten hyvinvoinnin kohentaminen tuottaa tilalle hyötyä. Lisäksi toimenpiteiden kustannukset on hyötyjä helpompi selvittää. Tutkimusten perusteella kotieläintilan tehokkuuden ja eläinten hyvinvointi-indikaattoreiden välillä voi olla positiivinen tai negatiivinen yhteys (vrt. Alvarez ym. 2008, Carbera ym. 2010, Allendorf ja Wettemann 2015, Barnes ym. 2011, Odermatt ym. 2019). Heise ym. (2018) havaitsivat, että eläinten hyvinvointiohjelmaan osallistumien ei vaikuttanut merkittävästi tuottajien itse kokemaan taloudelliseen menestykseen.

Jo lakisääteisten vaatimusten toteuttaminen aiheuttaa tiloille kustannuksia. Menghi ym. (2011) arvioivat eläinten hyvinvointia, elintarvikkeiden turvallisuutta ja ympäristönsuojelua koskevan EUlainsäädännön noudattamisen kustannuksia. Heidän mukaansa kustannukset eläinten hyvinvointia koskevista säännöksistä ja direktiiveistä, joilla torjutaan eläintauteja ja elintarvikkeista peräisin olevia taudinaiheuttajia olivat noin $8 \%$ sikatuotannon kustannuksista. Aiemmin Grethe (2007) oli todennut eläinten hyvinvointia koskevien vaatimusten noudattamisesta EU:ssa aiheutuviksi kustannuksiksi enintään 6 \% sianlihan tuotantokustannuksista. Myös Majewski ym. (2012), Spiller ym. (2015) sekä Grethe, (2017) ovat tarkastelleet eläinten hyvinvointia kohentavien lisätoimenpiteiden kustannuksia.

Tämän tutkimuksen päämääränä on kartoittaa tuotantoketjun taloudellista näkökulmaa eläinten hyvinvoinnista kertovaan laatumerkintään Suomessa. Esimerkkinä käytettiin sikatuotantoa ja siihen ehdotettuja toimenpiteitä, joiden taloudellisia hyötyjä ja haittoja ja sopivuutta sikatuotantoon tarkasteltiin sidosryhmätyöpajan, alan kirjallisuuden ja katetuottolaskelmien avulla. 


\section{Materiaali ja menetelmät}

\section{Laatumerkinnän lähtökohta}

Eläinten hyvinvointia kuvaava laatumerkintä on todennettu organisaatio, joka määrittelee arvolupaukset, joita merkintää käyttävät tuotteet antavat asiakkaille, sekä todentaa vaatimusten toteutumisen. Organisaation keskeisenä tehtävänä voi olla tuotantotavan määrittely ja sen dokumentointi sekä toiminnan ja tiedon hallinta (Kuva 1). Tärkeää on, että toimenpiteiden toteutuminen voidaan todentaa luotettavasti esimerkiksi riippumattoman ulkopuolisen toimijan avulla. Tärkeää on myös se, että tuotteiden erillään pito ja jäljitettävyys läpi tuotantoketjun ovat kunnossa. Nämä toimenpiteet aiheuttavat organisaatiolle kustannuksia. Lisäksi organisaatio voi toteuttaa merkin viestintää ja markkinointia, rahoitusta, hallinnointia, koulutusta ja muuta toimintaa. Näiden kustannusten suuruuteen vaikuttavat organisaation rakenteen "raskaus" sekä merkintää hyödyntävän tuotannon volyymi.

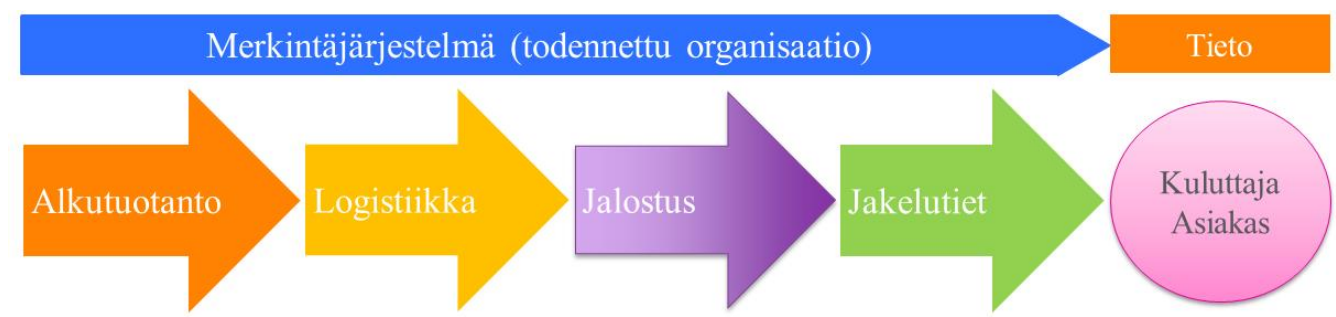

Kuva 1. Havainnekuva eläinten hyvinvointimerkintää kuvaavasta arvoketjusta alkutuotannosta kulutukseen asti

\section{Sikatuotannossa tarkastellut hyvinvointitoimenpiteet}

Tarkasteluun valitut hyvinvointitoimenpiteet perustuivat tieteelliseen kirjallisuuteen eläinten hyvinvoinnista (Wallenius 2020), sidosryhmäasiantuntijoiden kanssa pidettyihin työpajoihin sekä sidosryhmille tehtyyn Webropol-kyselyyn hyvinvointikriteerien tärkeydestä. Nämä työvaiheet oli toteutettu ennen tässä raportoitavaa tutkimusta. Tarkasteluun pyrittiin valitsemaan teemoja Welfare Quality® (WQ) -mittausmenetelmän (Botreau 2009) kaikilta neljältä osa-alueelta: hyvä ruokinta, hyvä kasvatusympäristö, hyvä terveys ja tarkoituksenmukainen käyttäytyminen. Menetelmä sisältää sekä eläinperäisiä mittareita, kuten eläimen ihon kunto tai käyttäytyminen, että resurssiperäisiä mittareita. Resurssiperäiset mittarit ovat perinteisesti enemmän käytettyjä eläinten hyvinvointivointimerkinnöissä, koska ne ovat eläinperäisiä mittareita helpompia mitata ja viestiä.

Tässä tutkimuksessa tarkasteluun valittiin kahdeksan sikatuotantoa koskevaa eläinten hyvinvointitoimenpidettä:

- Lisäelintilan tarjoaminen elintilaa sioille

- Vapaa porsiminen

- Vapaa tiineytys

- Ulkoilumahdollisuuden tarjoaminen sioille

- Laadukkaan tonkimismateriaalin tarjoaminen jatkuvasti soille

- Hyvä eläinten kohtelu ja käsittely -koulutus eläintenhoitajille

- Ennaltaehkäisevä terveydenhuolto, joka voidaan osittain todentaa eläimistä

- Hyvinvointi-indeksi hyvinvoinnin kohentamisessa, joka voidaan osittain todentaa eläimistä

\section{Toimenpiteiden kustannusten määrittäminen}

Toimijoiden näkökulmia teemaan kartoitetaan yhtäältä toimenpiteiden kustannus- ja katetuottolaskennan ja tutkimuskirjallisuuden sekä toisaalta työpajassa esitettyjen näkemysten pohjalta. Laskelmat laadittiin kuvaamaan vuoden 2019 tilannetta. Hintatiedot kerättiin pääosin Luonnonvarakeskuksen tilastoista sekä alan yrityksistä. Lisäksi tuotostasoa määritettäessä hyödynnettiin InterPig-vertailun tuloksia. Vapaaporsituksen laskelmat perustuivat Jääskeläisen ym. (2013) esittämiin skenaarioihin, jotka päivitettiin vastaamaan nykytilannetta. Toimenpiteiden vaikutukset tuotostasoon selvitettiin tutkimuskirjallisuudesta. 


\section{Alan toimijoiden ja sidosryhmien näkemykset hyvinvointitoimenpiteiden toteuttamisesta}

Tutkijaryhmä järjesti kesäkuussa 2019 työpajan, jossa käsiteltiin alan toimijoiden ja sidosryhmien näkemyksiä kahdeksaan hyvinvointitoimenpiteeseen. Työpajaan osallistui 11 henkilöä. Työpajassa kutakin toimenpidettä tarkasteltiin neljästä eri näkökulmasta: 1) eläimen ja sen hyvinvoinnin, 2) tuottajan ja hänen hyvinvointinsa, 3) talouden (maatila ja koko ketju) ja 4) kuluttajan näkökulmasta. Työpajassa kirjattiin muistiin osallistujien näkemyksiä siitä, miten toimenpiteet vaikuttavat eläimiin, tuottajiin, kuluttajiin ja talouteen. Osallistujilla oli myös mahdollisuus esittää muita kuin ennalta valittuja toimenpiteitä. Työpajan lopussa kukin toimenpide pyrittiin määrittämään hyvinvointimerkin perustason, "plus-tason" tai "premium-tason" toimenpiteeksi. Tämä toimenpiteiden ryhmittely oli myös työpajatyöskentelyn eräs keskeinen tavoite.

Lisäksi tutkijaryhmä ryhmitteli toimenpiteet työpajan jälkeen niiden ennakoitujen kustannusten ja hyötyjen sekä aiemmin tehdyn kuluttajakyselyn (Heinola ym. 2020) tulosten perusteella kolmeen eri ryhmään sen mukaan, miten houkuttelevilta toimenpiteet vaikuttivat kustakin näkökulmasta suhteessa muihin tarkasteltuihin toimenpiteisiin.

\section{Tulokset}

\section{Hyvinvointimerkinnän kustannukset ja hyödyt yleisesti}

Eläinten hyvinvointia kuvaavasta laatumerkinnästä aiheutuu sikatiloille ja muille ketjun toimijoille erilaisia kustannuksia. Vaikutukset voivat olla monisyisiä Esimerkiksi lisäkarsinatilan tarjoamisen myötä kiinteät kustannukset ja työ jakautuvat pienemmälle liha- tai eläinmäärälle ja tuottoja saadaan vähemmän per tila, ellei samalla lisätä sikalan kapasiteettia. Hyötyjä puolestaan saadaan muun muassa sairaus-, lääkitys- ja työkulujen vähenemisenä. Rakennuksiin saatetaan joissain toimenpiteissä joutua tekemään muutoksia, esimerkiksi emakoiden häkeistä luovuttaessa ja niihin voi liittyä erilaisia hankintoja ja investointeja. Myös sikalan puhtaanapidosta, siivouksesta ja hoidosta voi aiheutua lisäkustannuksia, kuten ulkoilualueiden hoito. Lisäksi toimenpiteet voivat aiheuttaa materiaali- ja tarvikekuluja, esimerkiksi virike- ja kuivikemateriaalien vuoksi. Päivittäin tehtävissä toimenpiteissä pienikin päiväkohtainen kustannus voi olla suuri, kun se lasketaan tuotettua lihasikaa kohti.

Joissain tapauksissa, kuten vapaaporsitukseen siirryttäessä, tilalla on mahdollisuus eläinten hyvinvointikorvaukseen, mikä voi kattaa osan kustannuksista. Eläinten hyvinvointikorvauksen jatkuvuudesta ja tasosta tulevilla ohjelmakausilla ei kuitenkaan ole takeita. Muita hyötyjä saadaan etenkin sikojen terveyden paranemisen, tuotostason nousun ja työn sujuvuuden paranemisen kautta. Esimerkiksi hännänpurennan kaltaisia käyttäytymishäiriöitä voi esiintyä vähemmän ja eläinlääkäri ja lääkintäkulut voivat laskea.

Tilatason kustannusten lisäksi laatujärjestelmä itsessään aiheuttaa kustannuksia. Näitä kustannuksia aiheuttavat muun muassa merkinnät pakkauksiin, omavalvonta, työntekijöiden ja muiden henkilöiden koulutus ja pätevöittäminen, sertifiointi ja valvonta, tuotteiden, tuotannon ja osaamisen testaaminen, tuotteiden jäljitettävyyden ja erillään pidon varmistaminen, markkinointi, toiminnan dokumentointi ja hallinto, sekä erilaiset infrastruktuurit, järjestelmät, koneet ja laiteet, joita merkinnän toteuttaminen edellyttää. Suorien kustannusten lisäksi laadultaan epäkuranttien tuotteiden toimitus ja hävikki voivat aiheuttaa kustannuksia.

Eläinten hyvinvointimerkintää kuvaava laatujärjestelmä vaatii toimiakseen vähintään 1-2 työntekijää, heille toimitilat ja toimintaa tukevan infrastruktuurin, tietojärjestelmän ja toimintamenobudjetin. Lisäksi tuotteen markkinointiin ja lanseeraukseen vaaditaan mahdollisesti mittaviakin resursseja, riippuen toiminnan laajuudesta. Kustannukset jakava volyymi on tärkeä. Jos sikatuotannossa merkintäorganisaation kustannus on esimerkiksi $300000 €$ vuodessa ja kustannuksia on jakamassa 10\% kotimaan tuotannosta, kustannus on alle 2 senttiä $\mathrm{kg}^{-1}$ lihaa. Sen sijaan jos merkintää käyttää vain prosentti tuotannosta, kustannus on hieman alle 20 senttiä $\mathrm{kg}^{-1}$ lihaa. Volyymiin vaikuttaa paitsi merkintää hyödyntävien tilojen ja yritysten tuottaman lihan määrä, myös se, saadaanko kaikki ruhon 
osat markkinoitua lisäarvoa tuottavalla hinnalla. Jos markkinoilta saataisiin lisähintaa vain esimerkiksi kinkuille ja fileille, olisi näiden ruhonosien myynnillä katettava koko merkinnän kustannukset.

\section{Yksittäisten toimenpiteiden kustannukset ja hyödyt}

\section{Lisäelintilan kustannukset ja hyödyt}

Kuvassa 2 on esitetty esimerkkilaskelman tulos, jossa on tarkasteltu lihasikojen karsinatilan lisäämisen taloudellista vaikutusta lihasikalassa. Karsinatilan lisääntyessä kiinteät ja työkustannukset nousevat, mutta lihasikojen sairaudet (mm. hengitystiesairaudet) vähenevät ja tuotantotulokset paranevat karsinatilan lisääntyessä. Kustannusten nousu näyttäisi kuitenkin olevan kuitenkin suurempi kuin saavutettava tuottavuushyöty. Mahdollinen teuraspainon nousu voi kuitenkin nostaa karsinatilan lisäämisellä saatavia hyötyjä. Mikäli lihasikojen karsinatilan määrää nostetaan esimerkiksi 1 neliömetristä 1.2 neliömetriin lihasikaa kohti, olisi markkinoilta saatava noin viiden euron lisätuottolihasikaa kohti.

Lisäkarsinatilan kustannusvaikutuksia on tarkasteltu alan kirjallisuudessa (esim. Bornett ym. 2003). Ulkomaiset taloustutkimukset soveltuvat sellaisenaan Suomeen kuitenkin heikosti, koska suomalaiset tuotanto-olosuhteet poikkeavat karsinatilan osalta monien muiden maiden olosuhteista.

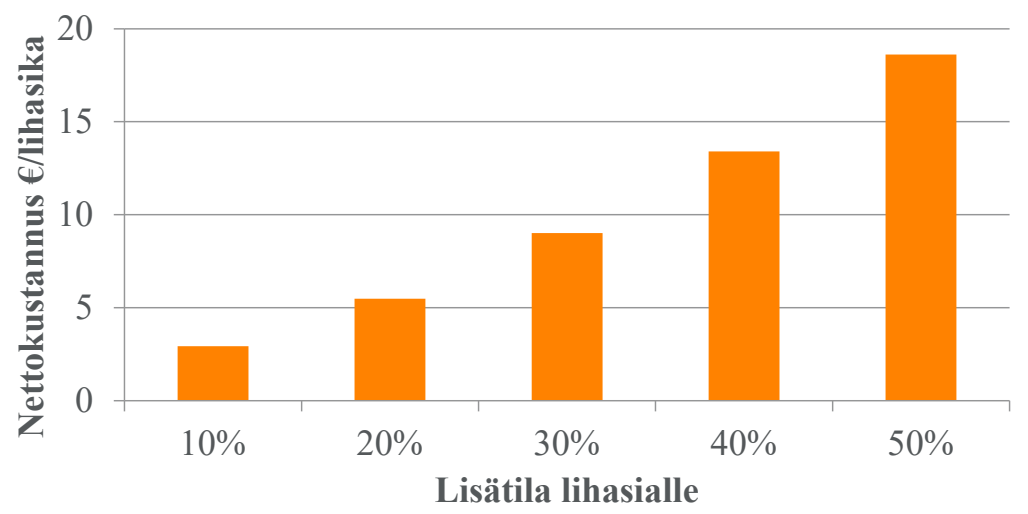

Kuva 2. Karsinatilan lisäämisen kustannusvaikutus, kun karsinatilaa lisätään $10 \%-50 \%$ lihasian loppukasvatuksen tilantarpeesta $\left(1 \mathrm{~m}^{2}\right.$ lihasika $^{-1}$; tuotosvaikutukset Flohr ym. (2018) perustuen)

\section{Vapaaporsituksen kustannukset ja hyödyt}

Jääskeläinen ym. (2013) tarkastelivat kustannuksia ja hyötyjä, jotka aiheutuvat, kun sikatuotannossa luovutaan porsitushäkeistä. Heidän tulostensa mukaan vapaaporsituksessa työ- ja rakennuskustannukset sekä muuttuvat kustannukset porsasta kohti voivat olla häkkiporsitusta korkeammat. Lisäksi tulokseen vaikutti, muuttiko tuotantotavan vaihtaminen porsaskuolleisuuteen.

Vapaaporsituksen kustannuksia ja hyötyjä on vertailtu eri tutkimuksissa etenkin Iso-Britanniassa. Guyn ym. (2012), tuotantokustannusvertailussa vapaaporsituksessa oli suurempi rakennuskustannus, isompi tilavaatimus ja korkeammat aidat. Mikäli vapaaporsitukseen siirtyminen ei vaikuttanut porsaiden kuolleisuuteen, tuotantokustannus vapaa-porsituksessa oli $0.6-1.4 € /$ porsas korkeampi kuin häkkiporsituksessa. Vosough Ahmadin ym. (2011) tuotantotapavertailussa porsituskarsina tuotantotapana puolestaan oli $34.7 € /$ emakko/vuosi kannattavampia kuin häkkiporsitus, muta häkkiporsituksessa oli $3.8 \%$ korkeampi porsaskuolleisuus. Baxterin ym. (2012) porsitusjärjestelmävertailussa oli muotoillut karsinat, joissa oli alueita eri toiminnoille, ja ne maksoivat noin $17 \%$ enemmän kuin porsitushäkit, mutta työmenekki oli molemmissa samankaltainen. Häkkiporsituksessa oli $3.4 \%$ alempi porsaskuolleisuus ja vertailussa taloudellinen nettokustannus oli $0.96 € /$ porsas. Cainin ym. (2013) tuotantotapavertailussa sen sijaan häkkiporsituksen tuotantokustannus oli $1.71 € /$ sika pienempi kuin ilman häkkejä tuotannossa

Laskimme vapaaporsitukseen siirtymisen kustannukset ja hyödyt Suomessa käyttäen Jääskeläisen ym. (2013) skenaarioita, joiden hinta, tuotostaso- ja tukitiedot päivitettiin vuotta 2019 vastaaviksi. Tulosten 
perusteella vapaaporsitukseen siirtyminen nostaa tuotantokustannuksia (työ, muuttuvat ja kiinteät kustannukset) ja voi lisätä porsaiden kuolleisuutta. Eläinten hyvinvointikorvaus kattaa kohonneet kustannukset laskelmassa käytetyissä skenaarioissa, jolloin pitkällä aikavälillä, mikäli eläinten hyvinvointikorvaus säilyy nykytasolla, vapaaporsituksen hyväksi tehtäville panostuksille saatava korvaus voi olla 6-8 euroa tuotettua lihasikaa kohti. Vapaaporsitukseen siirtymiseksi tarvittavien muutosinvestointien suuruus ja investoinnin käyttöaika kuitenkin vaikuttaa toimenpiteen kannattavuuteen.

\section{Vapaa tiineytys}

Työpajakeskusteluissa vaapaatiineytyksen etuina mainittiin kiimantarkkailun helpottuminen sekä jalkaterveyden ja porsaiden elinvoimaisuuden paraneminen. Osallistujat myös korostivat, että onnistuakseen vapaatiineytys vaatii huolellista suunnittelua. Vapaatiineytyksen haittoina mainittiin mahdollinen negatiivinen vaikutus tuotannon tehokkuuteen ja työturvallisuuteen sekä kiinteiden kustannusten ja työkustannusten lisääntyminen.

\section{Hyvä eläinten kohtelu ja käsittely -koulutus eläintenhoitajille}

Tutkimusten mukaan eläinten hoitajien kouluttautuminen on hyödyllistä. Pantujan ym. (2013) amerikkalaistutkimuksessa eläintenhoitajien koulutusohjelma laski sikojen hoitokustannuksia noin 0.5 eurolla per porsas tai lihasika. Suomessa ei ole tutkittu koulutusohjelmien merkitystä, mutta niiden voidaan odottaa vaikuttavan myönteisesti sikatilan toimintaan. Eläinten hoitajille suunnattu hyvä kohtelu ja käsittely-koulutus voi lisätä työmenekkiä sekä koulutuksen että sikojen tarkkailuun käytetyn ajan vuoksi. Se voi kuitenkin myös sujuvoittaa tilan töitä, kuten eläinten siirtoja, ja auttaa eläinten hoitajia kiinnittämään huomiota tärkeimpiin tekijöihin. Hoidon parantaminen voi vähentää sikojen kuolleisuutta ja poistumaa, lisätä ensiluokkaisten porsaiden tuotantoa sekä laskea sairauksien hoitokustannuksia, kuten Pantujan ym. (2013) tulokset osoittavat.

Emakoiden hyvän kohtelun hyödyistä on esimerkkejä muun muassa Prohealth-hankkeessa tehdyssä kokeessa, jossa emakoita rapsutettiin porsimisen lähipäivinä lyhyesti joka päivä. Tulosten mukaan työaika sikalassa oli noin $0.15 \mathrm{~h} /$ pahnue suurempi ja nettohyöty $0.8-2.4$ euroa per porsas (Niemi ym. 2020) Paremmin käsitellyillä emakoilla voi olla taipumus pysyä terveempänä, tarvita vähemmän lääkehoitoa ja porsailla selvitä elossa.

\section{Laadukasta tonkimismateriaalia aina saatavilla}

Työpajavastauksissa tonkimismateriaalin tarjoamisen sioille arvioitiin kohentavan paitsi sikojen hyvinvointia, myös eläinten hoitajien työtyytyväisyyttä ja vähentävän sairauksien määrää sioilla, kuten hännänpurentaa. Lisäksi nykyisen ohjelmakauden eläinten hyvinvointikorvaus tukee toimenpiteitä, joissa sioille tarjotaan tonkimismateriaalia. Toimenpiteen haittoina mainittiin, että työ- ja materiaalikustannukset nousevat. Lisäksi tuotiin esille tonkimismateriaalin mahdollisesta epähygieenisyydestä aiheutuvat tautiriskit.

D’Eath ym. (2016) tarkastelivat neljää hännänpurentaskenaariota, joista yhdessä karsinaan oletettiin annettavan päivittäin 200 grammaa silputtua olkea per lihasika. Tällöin olkien materiaalikustannuksiksi arvioitiin noin yksi euro teurastettua lihasikaa kohti. Tämän lisäksi oljen runsas käyttö lisäsi työkustannuksia, koska karsinaa oli siivottava enemmän ja olkea jaettava sioille päivittäin enemmän. Työkustannusten nousu oli noin 3 euroa lihasikaa kohti, mutta tähän kustannuserään sisältyi myös normaalia summaan karsinan siivouksen lisäkustannus.

\section{Ulkoilumahdollisuus sioille}

Työpajakeskusteluissa ulkoilumahdollisuuden koettiin parantavan sikojen hyvinvointia ja terveyttä ja mahdollistavan sikojen luontaisen käyttäytymisen. Myös työtyytyväisyyden koettiin paranevan. Nykyisellä ohjelmakaudella ulkoilevilla emakoilla ja ensikoilla on myös mahdollisuus eläinten hyvinvointikorvaukseen. 
Negatiivisena näkökohtana sikojen ulkoilussa nostettiin esille tautiriskien kasvaminen. Tämän pelättiin nostavan myös tautivahinkoja korvaavien vakuutusten maksuja. Keskustelussa mainittiin muun muassa afrikkalaisen sikarotuon, salmonellan, yersinian, toksoplasman ja trikiinien riskit. Myös työ- ja kiinteiden kustannusten nousu ja mahdollinen negatiivinen vaikutus teuraslaatuun tuotiin esille.

\section{Ennaltaehkäisevä terveydenhuolto ja hyvinvointi-indeksi}

Ennaltaehkäisevä terveydenhuolto ja hyvinvointi-indeksi, joka kuvaa eläimen kokonaishyvinvointia, toteutuvat nykyisin tietyssä muodossa terveysluokitusrekisteri Sikavassa. Työpajakeskusteluissa ennaltaehkäisevän toimenpiteen hyödyiksi mainittiin muun muassa lääkkeiden käyttötarpeen ja poikkeamien vaatiman työmäärän väheneminen. Tällä on myös antibioottiresistenssin kehittymistä ehkäisevä vaikutus. Hyvinvointi-indeksi puolestaan on osittain eläinperusteinen mittari, joka auttaa kohentamaan eläinten hyvinvointia ja terveyttä kattavasti ja voi toimia neuvonnallisena työkaluna. Haittapuolina mainittiin terveydenhuoltojärjestelmän ja eläinlääkärikäyntien kulut sekä hyvinvointiarvioinnin kustannukset

Ennaltaehkäisevä terveydenhuolto on toimenpide, joka hyödyttää koko sianlihan tuotantoketjua. Sen sijaan hyvinvointi-indikaattorien ja sikalan taloudellisten tunnuslukujen yhteydestä on vähemmän tutkimusnäyttöä. Henningsen ym. (2017) havaitsivat suuria eroja tanskalaisten sikatilojen katetuotossa ja eläinten hyvinvointia kuvaavissa indikaattoreissa. Näiden kahden indikaattorin välinen suhde oli heikko, mutta sillä oli taipumus olla positiivinen. Tämä voi osittain johtua siitä, että hyvä yrityksen johtaminen saattaa vaikuttaa myönteisesti sekä taloudelliseen tulokseen että eläinten hyvinvointiin. Heidän tutkimuksessaan keskityttiin eläinsuojelurikkomuksiin, jolloin yhteys saattaa olla voimakkaampi kuin jos vertailua suoritettaisiin esimerkiksi Welfare Quality-pisteisiin.

Sampolahti (2013) havaitsi, että suomalaisten sikatilojen Welfare Quality-pisteillä ja katetuotolla oli taipumus korreloida positiivisesti. Korrelaatioiden tilastollinen merkitsevyys oli kuitenkin heikko. Merkittävimmät korrelaatiot myyntimarginaaliin löytyivät tekijöistä, jotka liittyvät ruokintaan, riittävään määrään juomakappaleita, vammojen ja sairauksien ehkäisyyn sekä sikojen ja heidän talonmiehensä hyviin suhteisiin. Erityisesti työpanoksen havaittiin korreloivan sekä maatilan taloudellisten tulosten että eläinten hyvinvoinnin kanssa. Tämä viittaa siihen, että työvoimalla voi olla tärkeä rooli sekä taloudellisen tuloksen että eläinten hyvinvoinnin saavuttamisessa.

\section{Toimenpiteiden luokittelu toisiinsa verrattuna}

Työpajassa perustason hyvinvointimerkinnässä vaadittaviksi toimenpiteiksi valittiin lisäelintilan sekä laadukkaan tonkimismateriaalin tarjoaminen (aina saatavilla) sioille, hyvä eläinten kohtelu ja käsittely -koulutus eläintenhoitajille, ennaltaehkäisevä terveydenhuolto sekä hyvinvointi-indeksin käyttöönotto. Osa näistä toimenpiteistä on jo melko laajasti käytössä sika-alalla, ja osa ei ole. Hieman vaatiman plustason toimenpiteeksi valittiin vapaa tiineytys ja vaativimmalle premium-tasolle sopiviksi toimenpiteiksi valittiin vapaa porsiminen/vapaa imetys sekä sikojen ulkoilumahdollisuus.

Hyvä eläinten kohtelu ja käsittely -koulutus eläintenhoitajille sekä ennaltaehkäisevä terveydenhuolto olivat perustason toimenpiteitä kaikista kolmesta näkökulmasta. Lisäksi hyvinvointi-indeksi sisällytettiin perustasolle talouden näkökulmasta, sillä Sikavassa on tehty hyvinvointi-indeksin käyttöönottoon liittyvää työtä. Talouden näkökulmasta merkittävä lisäelintilan tarjoaminen sekö ulkoilumahdollisuus sijoitettiin premium-tasolle, mutta kuluttajakyselyn perusteella ne sijoittuisivat keskimmäiselle plus-tasolle. Sen sijaan vapaa porsiminen (vapaa imetys) sijoitettiin talouden näkökulmasta plus-tasolle, koska siihen voi tällä ohjelmakaudella saada eläinten hyvinvointikorvausta. 
Taulukko 1. Tarkasteltujen toimenpiteiden houkuttelevuus työpajakeskusteluiden, taloudellisen tarkastelun sekä kuluttajakyselyn perusteella*

\begin{tabular}{|l|c|c|c|}
\hline & \multicolumn{3}{|c|}{ Sika } \\
\hline Toimenpide & Työpaja & Talous & Kuluttaja** \\
\hline Enemmän elintilaa & 1 & 3 & 2 \\
\hline Vapaa porsiminen (vapaa imetys) & 3 & 2 & 2 \\
\hline Vapaa tiineytys & 2 & 2 & 3 \\
\hline Ulkoilumahdollisuus & 3 & 3 & 2 \\
\hline Laadukasta tonkimismateriaalia aina saatavilla & 1 & 2 & 2 \\
\hline Hyvä eläinten kohtelu ja käsittely -koulutus eläintenhoitajille & 1 & 1 & 1 \\
\hline Ennaltaehkäisevä terveydenhuolto & 1 & 1 & 1 \\
\hline Hyvinvointi-indeksin käyttöönotto & 1 & 1 & 2 \\
\hline
\end{tabular}

*Asteikko: 1= "Laajimmin kiinnostava" toimenpide (esitetyistä vaihtoehdoista).

$3=$ "Suppeimmin kiinnostava" toimenpide (esitetyistä vaihtoehdoista).

** Heinolan ym. (2020) tekemän kyselyn tuloksiin perustuen.

\section{Tulosten tarkastelu}

Perustason toimenpiteinä ennaltaehkäisevä terveydenhuolto, eläinten käsittely- ja kohtelukoulutus ja hyvinvointi-indeksi saivat eniten kannatusta. Premium-tasolle valikoitui vapaaporsituksen ja sikojen ulkoilun kaltaisia toimenpiteitä, joiden toteutus voi lisätä tuotantokustannuksia ja vaatia investointeja. Alan toimijoiden näkökulma sikojen ulkoiluun on kuitenkin hyvin kriittinen, koska siihen liittyy merkittäviä elintarviketurvallisuus- ja eläintautiriskejä. Ulkoilun toteuttaminen edellyttäisi, että nämä riskit saadaan ensin hallintaan ulkoilussa. Merkittävä lisätilan tarjoaminen, ulkoilu ja vapaaporsitus näyttäisivät aiheuttavan eniten lisäkustannuksia

Tutkimustyöpajan perusteella eläinten hyvinvointimerkinnän on oltava uskottava ja yhtäältä parannettava eläinten hyvinvointia ja toisaalta myös markkinoitava kotimaisen tuotannon vahvuuksia. Tämän vuoksi on tärkeää huomioida markkinoiden asettamat reunaehdot ja kuluttajien odotukset. Laatumerkintäjärjestelmän käyttö aiheuttaa kustannuksia, jotka on katettava joko tuottavuusparannuksilla, yhteiskunnan maksamalla tuella tai markkinoilta saatavilla lisätuotoilla. Toimenpiteiden toteutuksessa olisi perusteltua hyödyntää Sikavaa, investointitukia ja eläinten hyvinvointikorvausta siten, että nämä kolme ohjaisivat tuotantopäätöksiä samaan suuntaan. Toimenpiteistä osa voidaan osarahoittaa eläinten hyvinvointikorvauksen avulla, mutta sen jatkuvuus aiheuttaa taloudellisia riskejä ohjelmakausien vaihtuessa.

Olennaista myös se, että kustannuksia jakamassa on riittävän suuri osuus tuotannosta ja ruhonosista. Merkin taustalle tarvitaan riittävä volyymi, mutta merkintä ei välttämättä voi kattaa kaikkea tuotantoa, ainakaan premium-tasolla, jonka tuotteiden kysyntä lienee rajallisempaa kuin perustason tuotteiden kysyntä. Viestintä on myös kriittinen tekijä markkinatuottojen realisoitumisessa. Tämän vuoksi voi olla perusteltua nostaa viestinnän kärkeen 1-3 selkeästi mitattavaa asiaa, jotka kiinnostavat kuluttajia. Ratkaistava on myös se, missä määrin ja millä tavoin merkki profiloi kotimaista ja ulkomaista tuotantoa suhteessa toisiinsa.

Merkintää kehitettäessä on myös huomioitava kilpailunäkökulma. Tuotantotapaa kuvaava laatumerkintä on rinnastettavissa kilpailuoikeudellisessa mielessä standardointiin, joka määrittelee tuotannon tekniset tai laadulliset vaatimukset. Laatumerkin saamisen ehtojen tulisi olla sellaisia, että ne eivät rajoita kilpailua. Tämä tarkoittaa muun muassa toimijoiden tasavertaista pääsyä merkintään, ehtojen kohtuullisuutta, ja vapaata osallistumista vaatimusten laatimiseen ja läpinäkyvää hyväksymismenettelyä. Tämän vuoksi hankkeen työpajoihin on kutsuttu erilaisia kotieläinalan toimijoita. 


\section{Johtopäätökset}

Tulokset viittaavat siihen, että perustason laatumerkissä toimenpiteinä voisivat olla sopiva lisäelintilan sekä laadukkaan tonkimismateriaalin tarjoaminen (aina saatavilla) sioille, hyvä eläinten kohtelu ja käsittely -koulutus eläintenhoitajille, ennaltaehkäisevä terveydenhuolto sekä hyvinvointi-indeksin käyttöönotto. Premium-tasolla merkintä voisi sisältää vapaaporsituksen ja sikojen ulkoilun kaltaisia toimenpiteitä. Ulkoilun toteuttaminen edellyttäisi, että nämä riskit saadaan ensin hallintaan ulkoilussa.

Toimijoiden mukaan hyvinvointimerkintä ei kuitenkaan saisi vaarantaa tuoteturvallisuutta. Toimenpiteiden toteutuksessa olisi perusteltua hyödyntää Sikavaa, investointitukia ja eläinten hyvinvointikorvausta siten, että nämä kolme ohjaisivat tuotantopäätöksiä samaan suuntaan. Tukijärjestelmän osalta huomiota tulisi kiinnittää sen riittävään jatkuvuuteen.

\section{Kiitokset}

Tämä tutkimus on osa Eläinten hyvinvointimerkintä suomalaisen eläintuotannon kilpailukyvyn ja laadun edistäjänä-hanketta. Tässä kirjoituksessa esitetyt näkemykset eläinten hyvinvointimerkinnästä ovat tutkijaryhmä näkemyksiä. Kiitos hankkeen rahoittajille (Maatilatalouden kehittämisrahasto, Atuottajat, HKScan, Valio, Arla, Juustoportti food, Lidl, Maa- ja metsätaloustuottajain keskusliitto ja SEY Suomen Eläinsuojelu) sekä yhteistyökumppaneille ja työpajoihin osallistuneille henkilöille.

\section{Kirjallisuus}

Allendorf, J.J. \& Wettemann, P.J.C. 2015. Does animal welfare influence dairy farm efficiency? A two-stage approach. Journal of Dairy Science 98: 7730-7740. https://doi.org/10.3168/jds.2015-9390

Bennett, R. 2012. Economic rationale for interventions to control livestock disease. Eurochoices 11: 5-10. https://doi.org/10.1111/j.1746-692X.2012.00227.x

Alvarez, A., del Corral, J., Solís, D. \& Pérez, J.A. 2008. Does intensification improve the economic efficiency of dairy farms? Journal of Dairy Science 91: 3693-3698. https://doi.org/10.3168/jds.2008-1123

Barnes, A.P., Rutherford, K.M.D., Langford, F.M. \& Haskell, M.J. 2011. The effect of lameness prevalence on technical efficiency at the dairy farm level: An adjusted data envelopment analysis approach. Journal of Dairy Science 94: 5449-5457. https://doi.org/10.3168/jds.2011-4262

Baxter, E.M., Lawrence, A.B. \& Edwards, S.A. 2012. Alternative accommodation: Welfare and economic aspects of existing farrowing and lactation systems for pigs. Animal 6: 96-117.

https://doi.org/10.1017/S1751731111001224

Bornett, H.L.I., Guy, J.H. \& Cain, P. 2003. Impact of Animal Welfare on Costs and Viability of Pig Production in the UK. Journal of Agricultural and Environmental Ethics 16: 163. https://doi.org/10.1023/A:1022994131594

Botreau, R., Veissier, I. \& Perny, P. 2009. Overall assessment of animal welfare: strategy adopted in Welfare Quality ${ }^{\circledR}$. Animal Welfare 18: 363-370.

Cain, P.J., Seddon, Y.M., Baxter, E.M. \& Edwards, S.A. 2012. Economic evaluation of high welfare indoor farrowing systems for pig. Animal Welfare 21(SI): 19-24.

https://doi.org/10.7120/096272812X13345905673520

Cabrera, V.E., Solís, D. \& del Corral J. 2010. Determinants of technical efficiency among dairy farms in Wisconsin. Journal of Dairy Science 93: 387-393. https://doi.org/10.3168/jds.2009-2307

Cicia, G. \& Colantuoni, F. 2010. Willingness to pay for traceable meat attributes: a meta-analysis. Journal of Food System Dynamics 1: 3.

Clark, B., Panzone, L.A., Stewart, G.B., Kyriazakis, I., Niemi, J.K., Latvala, T., Tranter, R., Jones, P. \& Frewer, L.J. 2019. Consumer attitudes towards production diseases in intensive production systems. PLoS ONE 14: e0210432. https://doi.org/10.1371/journal.pone.0210432

Council of the European Union 2019. Council conclusions on animal welfare - an integral part of sustainable animal production. December 2019. (OR. en) 14975/19. Brussels, Belgium: Council of the European Union. 16. Cited 9 February 2020. https://www.consilium.europa.eu/media/41863/st14975-en19.pdf

D'Eath, R., Niemi, J., Vosough Ahmadi, B., Rutherford, K., Ison, S., Turner, S., Anker, H. T., Jensen, T., Busch, M. E., Jensen, K. K., Lawrence, A. B. \& Sandøe, P. 2016. Why are most EU pigs tail docked? Economic and ethical analysis of four pig housing and management scenarios in the light of EU legislation and animal welfare outcomes. Animal 10: 687-699. https://doi.org/10.1017/S1751731115002098 
European Commission 2016. Attitudes of Europeans towards Animal Welfare. Special Eurobarometer 442. Brussels, Belgium: European Commission.

Flohr, J., Dritz, S., Tokach, M., Woodworth, J., DeRouchey, J., \& Goodband, R. 2018. Development of equations to predict the influence of floor space on average daily gain, average daily feed intake and gain: Feed ratio of finishing pigs. Animal 12: 1022-1029. https://doi.org/10.1017/S1751731117002440

Grethe, H. 2007. High animal welfare standards in the EU and international trade - How to prevent potential 'low animal welfare havens'? Food Policy 32: 315-333. https://doi.org/10.1016/j.foodpol.2006.06.001

Grethe, H. 2017. The Economics of Farm Animal Welfare (October 2017). Annual Review of Resource Economics 9: 75-94. https://doi.org/10.1146/annurev-resource-100516-053419

Guy, J.H., Cain, P.J., Seddon, Y.M., Baxter, E.M. \& Edwards, S.A. 2012. Economic evaluation of high welfare indoor farrowing systems for pig. Animal Welfare 21(SI): 19-24.

https://doi.org/10.7120/096272812X13345905673520

Hansson, H. \& Lagerkvist, C.J. 2015. Identifying use and non-use values of animal welfare: Evidence from Swedish dairy agriculture. Food Policy 50: 35-42. https://doi.org/10.1016/j.foodpol.2014.10.012

Heinola, K., Latvala, T., Raussi, S., Kauppinen, T, \& Niemi, J. K. 2020. Kuluttajanäkökulmia eläinten hyvinvointimerkin kehittämiseen. Suomen Maataloustieteellisen Seuran Tiedote 38.

https://doi.org/10.33354/smst.89454

Heise, H., Schwarze, S. \& Theuvsen, L. 2018. Economic effects of participation in animal welfare programmes: does it pay off for farmers? Animal Welfare 27: 167-179. https://doi.org/10.7120/09627286.27.2.167

Henningsen, A., Czekaj, T.G., Forkman, B., Lund, M. \& Nielsen, A.S. 2018. The Relationship between Animal Welfare and Economic Performance at Farm Level: A Quantitative Study of Danish Pig Producers. Journal of Agricultural Economics 69: 142-162. https://doi.org/10.1111/1477-9552.12228

Jääskeläinen, T., Niemi, J. \& Karhula, T. 2013. Häkkiporsituksesta luopumisen tuotannolliset ja taloudelliset vaikutukset. Helsinki, Finland: Animal Welfare Centre, University of Helsinki. 54 s.

Kotro, J., Jalkanen, L., Kumpulainen, K., Järvinen, M. \& Forsman-Hugg, S. 2011. Mistä suomalainen ruokaketju voi olla ylpeä? Näkemyksiä suomalaisen ruoan lisäarvotekijöistä. Jokioinen, Finland: MTT Agrifood Research Finland. MTT kasvu 15.70 s.

Majewski, E., Hamulczuk, M., Malak-Rawlikowska, A., Gębska, M. \& Harvey, D. 2012. Cost-effectiveness assessment of improving animal welfare standards in the European agriculture. In: Selected Paper prepared for presentation at the International Association of Agricultural Economists (IAAE) Triennial Conference, Foz do Iguaçu, Brazil, 18-24 August, 2012. http://purl.umn.edu/126741. Cited 9 February 2020.

Lagerkvist, C.J. \& Hess, S. 2011. A meta-analysis of consumer willingness to pay for farm animal welfare. European Review of Agricultural Economics 38: 55-78. https://doi.org/10.1093/erae/jbq043

Menghi, A., de Roest, K., Porcelluzzi, A., Deblitz, C., von Davier, Z., Wildegger, B., de Witte, T., Strohm, K., Garming, H., Dirksmeyer, W., Zimmer, Y, Bölling, D., van Huylenbroek, G. \& Mettepenningen, E. 2011. Assessing farmers' cost of compliance with EU legislation in the fields of environment, animal welfare and food safety. Final report Commissioned by the European Commission Directorate-General for Agriculture and Rural Development. Brussels, Belgium: European Commission. Cited 9 February 2020.AGRI-2011-EVAL-08. https://ec.europa.eu/agriculture/sites/agriculture/files/external-studies/2014/farmer-costs/fulltext_en.pdf. McInerney, J.P. 2004. Animal welfare, economics and policy. Report to Defra, UK. Cited 9 February 2020. https://webarchive.nationalarchives.gov.uk/20110318142209/http://www.defra.gov.uk/evidence/economics/food farm/reports/documents/animalwelfare.pdf

MMM 2017. Ruoka2030 - Suomi-ruokaa meille ja maailmalle. Valtioneuvoston selonteko ruokapolitiikasta. Cited 9 February 2020. Helsinki, Finland: Ministry of Agriculture and Forestry.

https://mmm.fi/documents/1410837/1923148/Ruokapoliittinen+selonteko+Ruoka2030/d576b315-41fe-4e9d9d02-8462c5ae5895/Ruokapoliittinen+selonteko+Ruoka2030.pdf.

Niemi, J.K., Bennett, R., Clark, B., Frewer, L., Jones, P., Rimmlet, T. \& Tranter, R. 2020. A value chain analysis of interventions to control production diseases in the intensive pig production sector. Submitted to PlosOne.

Pantuja, L.G., Kuhn, M., Hoover, T., Amodie, D., Weigel, D., Dice, C., Moeller, T. \& Farrand, E. 2013. Impact of Husbandry Education Program on nursery pig mortality, productivity, and treatment cost. Journal of Swine Health and Production 21:188-194.

Odermatt, B., Keil, N. \& Lips, M. 2019. Animal welfare payments and veterinary and insemination costs for dairy cows. Agriculture 9: 3. https://doi.org/10.3390/agriculture9010003 
Sampolahti, T.H. 2018. Lihasikojen hyvinvoinnin yhteys tuotannon taloudelliseen tulokseen. Master thesis. Helsinki, Finland: Department of Economics and Management, Faculty of Agriculture and Forestry, University of Helsinki. $68 \mathrm{~s}$.

Spiller, A., Gauly, M., Balmann, A., Bauhus, J., Birner, R., Bokelmann, W., Christen, O., Entenmann, S., Grethe, H., Knierim, U., Latacz-Lohmann, U., Martínez, J., Nieberg, H., Qaim, M., Taube, F., Tenhagen, B.A., \& Weingarten, P. 2015. Wege zu einer gesellschaftlich akzeptierten Nutztierhaltung. Berichte über Landwirtschaft Sonderheft 221: 1-172.

Vosough Ahmadi, B., Stott, A.W., Baxter, E.M., Lawrence, A.B. \& Edwards, S.A. 2011. Animal welfare and economic optimization of farrowing systems. Animal Welfare 20: 57-67.

Wallenius, E. 2020. Factors affecting Animal Welfare with emphasis on the Finnish livestock production. Literature review. Julkaisematon käsikirjoitus.

YK 2005. United Nations General Assembly. 2005 World Summit Outcome, Resolution A/60/1, adopted by the General Assembly on 15 September 2005. 